\title{
Strategies for the development of international sport diplomacy in the volleyball federation of the Islamic Republic of Iran
}

\section{Estrategias para el desarrollo de la diplomacia deportiva internacional en la federación de voleibol de la República Islámica de Irán}

\author{
Reza Mir Fallah Nassiri ${ }^{1}$, Amir Hosein Monazami ${ }^{2}$, Najaf Aghaei ${ }^{3}$, Meysam Rahimizadeh ${ }^{2 *}$ \\ ${ }^{1}$ Department of Sport Management, Faculty of Physical Education and Sport Sciences, Shahid \\ Rajaee Teacher Training University, Iran. \\ ${ }^{2}$ Department of Sport Management, Faculty of Sport Sciences, Shahid Rajaei Teacher Training \\ University, Iran. \\ ${ }^{3}$ Department of Sport Management, Faculty of Physical Education and Sport Sciences, Kharazmi \\ University, Iran. \\ * Correspondence: Meysam Rahimizadeh; meysam.rahimizadeh@gmail.com
}

\begin{abstract}
In recent years, Iran's volleyball sport has made significant progress and the Iranian national team has been able to compete in the World Volleyball League. This situation has provided the Iranian Volleyball Federation with diplomatic opportunities. The purpose of this study was to develop strategies for the development of international sport diplomacy in the volleyball federation of the Islamic Republic of Iran. This study was conducted qualitatively by interviewing Iranian volleyball officials $(\mathrm{N}=4)$, academic experts in sport diplomacy $(\mathrm{N}=4)$ and internationally experienced coaches and referees $(N=5)$. Data analysis with theme analysis techniques revealed that the five emerging themes included: challenges, principles of effective international sport diplomacy, international sport diplomacy success factors, international diplomacy development strategies in volleyball federation, and the implications of international sport diplomacy, including 18 sub-themes and 43 open codes. All these aspects are analyzed and discussed in the present study.
\end{abstract}

\section{KEYWORDS}

Sport Diplomacy; International Sport; Volleyball 


\section{RESUMEN}

En los últimos años, el deporte de voleibol ha logrado un progreso significativo en Irán y el equipo nacional iraní ha podido competir en la Liga Mundial de Voleibol. Esta situación ha brindado oportunidades diplomáticas a la Federación Iraní de Voleibol. El propósito de este estudio fue desarrollar estrategias para el desarrollo de la diplomacia deportiva internacional en la federación de voleibol de la República Islámica de Irán. Este estudio se realizó de forma cualitativa entrevistando a funcionarios de voleibol iraníes $(\mathrm{N}=4)$, expertos académicos en diplomacia deportiva $(\mathrm{N}=4)$ y entrenadores y árbitros con experiencia internacional $(\mathrm{N}=5)$. El análisis de datos con técnicas de análisis temático reveló que los cinco temas emergentes incluían: desafíos, principios de la diplomacia deportiva internacional efectiva, factores de éxito de la diplomacia deportiva internacional, estrategias de desarrollo de la diplomacia internacional en la federación de voleibol y las implicaciones de la diplomacia deportiva internacional, incluyendo 18 subtemas y 43 códigos abiertos. Todos estos aspectos se analizan y discuten en el presente estudio.

\section{PALABRAS CLAVE}

Diplomacia Deportiva; Deporte Internacional; Voleibol

\section{INTRODUCTION}

Sport is a multidimensional social phenomenon globally. There are different theoretical perspectives for understanding sport and its functions, but in essence, it is an institutionalized and effective game. Sport is a global cultural heritage and explaining the relationship between sport and society is complicated. In summary, sport can be studied from a variety of social aspects, including political, economic, cultural, anthropological, psychological, educational, aesthetic, and legal. Other aspects of the sport including biological, medical, and technical can also be considered (Bazić, 2018).

When it comes to the role of sport in modern society, it can be argued that sport is a continuous social experiment in which man demonstrates and develops his potential. Having developmental, educational, patriotic, communication functions, sport contributes to the integration and coordination of individuals and social groups and the development of nations. The sport system is directly linked to the health and hygiene, scientific, cultural, and educational subsystems. In addition, the sport has a significant impact on the social, economic and political trends of modern societies (Essays, 2018). 
Denis and Grix (2012) state in Chapter 2 of the book Sport under Communism entitled "The Political Use of Sport": Before the widespread debate about the political use of sport by governments, noting that little scientific research Concerning the political analysis of sport conducted by two groups of political scientists and international relations researchers is valuable. Denis and Grix (2012) continue to refer to two distinct political uses of sport as extrinsic and intrinsic dimensions, with the extrinsic political use of sport largely focusing on the use of sport and sporting events by regimes, particularly the Olympics, to promote their ideologies, East German use of sport is an example of this kind of application. In this dimension, it is believed that elite sport usually represents the nation in international competitions and the national team of each country is considered equivalent to that nation. Despite the fact that in Avery Brundage's (chairman of the International Olympic Committee from 1952 to 1972) view sports and politics do not combine, we are interested in sports, not politics and business, but unfortunately, there are numerous examples of politically instrumental use of sport (or better to say abuse), such as the boycott of the 1980 Moscow Olympics and the 1984 Los Angeles Olympics, suggesting that this view has also been neglected by academics. Denis and Grix (2012) describe the range of political uses of sport in the domestic dimension, including efforts to reduce crime, stimulate social capital, and promote cohesion between disadvantaged and vulnerable groups. This section also outlines the benefits of combating obesity and reducing the need for health services, social inclusion, and enhancing citizens' general well-being for sports (Dennis \& Grix, 2012). Of course, by searching the words above in the information sources it can be claimed that more research has been done on the internal dimension of the political use of sport, which has been researched by experts in various disciplines such as social sciences, sociology, cultural studies, management, psychology, Physiology and so on.

Based on the definition of external and internal dimensions of political use of sport by Dennis and Grix (2012), considering that the present study focuses on the field of sports diplomacy, the external dimension of political use of sport is considered and developed.

The political use of sport (in extrinsic dimension, in relation to nations and other countries) is not limited to contemporary times. For thousands of years, there has been a close link between sports, politics and diplomacy. In the ancient Olympics, for example, for the protection of fans and competitors during matches between the countries and nations involved, the truce has been pointed to, and the Greek word ekecheiria refers to the impunity and prohibition of any attack and aggression during games. Murray (2012) identifies three types of the political use of sport. The first is the use of sport as a punitive tool, one being the fight against apartheid in South Africa. The second is a tool to conflate political relations, exemplified by the US-Soviet 1980 and 1984 Olympic-sanctioned 
Olympics, and the third as a means of bringing together old enemies and bringing them closer together. An example of this was the hosting of the 2002 World Cup by Japan and South Korea. Murray (2012) believes that the relationship between sport and politics has been much debated, but the theories and practices of sport and diplomacy remain largely unknown (Murray, 2012). In another study, Murray and Pigman (2014) again emphasize the lack of proper theorizing of the relationship between international sport and diplomacy and propose an analytical classification of divergence of international sport and diplomacy to compensate for deficiencies. There are two distinct types of relationships, according to the categorization carried out by these researchers: the first is the conscious use of governments of international sport as a diplomatic tool, and the second is international-sport-as-diplomacy. Representing diplomatic communications and negotiations between nongovernmental actors as a result of international sport competitions, according to Murray and Pigman (2014), the first type of sport diplomacy is more common in the world, while the latter is less common (Murray \& Pigman, 2014). A review of the political events that have taken place in the last 100 years in sporting competitions around the world also illustrates the prevalence of the former, namely the use of sport as a diplomatic tool, which has been of interest to researchers in various studies. Ping Pong Diplomacy between the United States and the People's Republic of China in the Early 1970s (Eckstein, 1993; Hong \& Sun, 2000; Kobierecki, 2016); Sport Diplomacy in Football and Wrestling between the United States and Iran (Chehabi, 2001); Cricket Diplomacy between India and Pakistan (Næss-Holm, 2007; Shahid, 2015); Sport diplomacy over the years between the countries of South Korea and North Korea (Merkel, 2008) are examples of this state, which have not ended up to the same results in all cases.

Murray (2012) cites seven different reasons for governments' increasing use of international sport as a diplomatic tool: 1.The post-Cold War diplomatic environment has transformed governments into modification, alteration, and experimentation of new methods and sport diplomacy is an active, innovative and groundbreaking contribution. 2. Sport and sports institutions In terms of strength, acceptance by people and range of activities are increasing. 3. Sport as a soft power has become a more effective tool than traditional diplomacy in bringing together people, nations, and countries that have been apart from each other. 4. Exercise is a major part of human life today and has a global audience. Sport events can provide many opportunities for interaction with outsiders. 5. The fifth reason is the increasing convergence and closeness of sports and diplomacy. Diplomacy represents peace, and sports are a powerful tool for achieving and even building relationships between governments. Using a positive message that includes shared values such as mutual respect, patience, compassion, order, and equality of opportunities, Sport Versus Different Ethical and 
Cultural Differences, can serve as a more effective foreign policy than promises or rewards to individuals. 6. Globalization is another reason for greater interaction and integration of diplomacy and sport. The role of athletes and diplomats is changing, and awareness of their social responsibilities is a popular demand for both professions. In this situation, sports and diplomacy are drawn to each other like two antilogous poles. 7. The last reason is that sport diplomacy is a soft way to normalize relations between conflicting countries.

As is evident today, there are no longer any doubts about sports usefulness as a diplomatic tool. This was also reflected in the thoughts of the founder of the Modern Olympic Games, Baron Pierre de Coubertin and is reflected in the Olympic Charter (International Olympic Committee, 2019). The United Nations and other subsidiary organizations such as UNESCO have also, at different times, focused on the role of sport in peace building. An example of these actions is the adoption of a UN resolution calling for a peaceful and better world through sport and the notion of Olympic in 1993 and the naming of April 6 as World Sport Day for Peace and Development (United Nations, 2020a, $2020 \mathrm{~b}$ ) all of which endorse the positive function of sport as a diplomatic tool.

Maybe even William J. Morgan, who founded volleyball 126 years ago, himself, did not think that one-day public interest in the sport he invented would be so pervasive that it becomes the most popular Olympic sport, and one of the world's top five sports, and The International Federation, with 220 national federations as members, would be the largest sports organization in the world that develops varied programs for the half-billion people who play volleyball. During the past years, the International Volleyball Federation has been organizing international programs, such as public volleyball, combball, volleyball for young people to adolescents, etc., which all represent the interest and attention of the international community in this field. In the past two decades, with the advent of beach volleyball, the fans of another section of sports that are considered not just competitive but also fun and touristic, have joined the field to enjoy beach volleyball from the very beginning of its international presence. Today, beach volleyball has been cited as one of the most profitable sports in the world, generating billions of dollars from its worldwide tours (FIVB, 2020).

Volleyball in Iran has been around for over 100 years, the Iranian Volleyball Federation became a member of the International Volleyball Federation in 1959, and since then, more international volleyball activities have taken place in Iran. Especially in recent years, we have witnessed the progress of Iranian volleyball in the world so that in 2019 Iranian volleyball was ranked eighth in the world (FIVB, 2019). Today, the continuing presence of the Iranian national volleyball team in volleyball League of Nations and the achievement of sporting successes, in addition to stirring up Iranian national pride and positive domestic influences, have also attracted 
much international attention. It has also provided Iran with the opportunity to host national teams from various countries (even countries with no political ties such as the United States). So it is clear that the situation can be used by Iran as an opportunity to facilitate international relations with different countries.

Women in Iran are prevented from attending men's sports in stadiums (still from animation). Meanwhile, volleyball has become one of Iran's most popular sports. The national team just qualified for the Olympics in Rio de Janeiro, Brazil, with a string of big wins. Iranians obsessively follow the national team and go to stadiums wherever possible to cheer it on. But for women, the ban is still in place, separating women and girls from their families and friends when the team plays at home.

At the international tournament last summer, Iranian women were shut out as Iranian authorities reneged on promises that women could attend, restricting ticket sales to men only. hardliners threatening to stop women from entering stadiums. This climate of fear and intimidation has been in place since 2014, when Ghoncheh Ghavami and several other Iranian women were arrested as they attempted to attend one of the volleyball matches at Azadi. While most were released soon thereafter, Ghavami was re-arrested, charged with "propaganda against the state," and held in Evin prison for nearly five months.

Government authorities inside the country are divided on this issue, as the debate over the ban continues. Defenders of the restrictions argue that stadiums are too dangerous for women, or (completely unrelatedly) that women's time is better spent doing household chores rather than watching volleyball.

Critics of the ban stress that the rights of half of the population cannot be denied without any clear legal basis. Last year, Shahindokht Mowlaverdi, the vice president for women's and family affairs, said that the national security council had determined that women attending sport stadiums is not against Islamic law, and that a framework for their attendance should be created.

As noted above, research indicates that international sport can be used as a tool for diplomacy and there are many examples, but citing Murray and Pigman's (2014) study that had introduced two aspects for sport International Relations; the second type, international-sport-as-diplomacy, which occurs during international sport competitions, has been less studied, so it can be said that there is a research gap in sport international diplomacy that needs to be further studied. Therefore, due to the specific conditions of Iranian volleyball and its presence in the high-level global competitions, the present study seeks to fill the gap in research on international sport diplomacy in the Iranian Volleyball Federation. Simply put, this qualitative research seeks to answer the question of how and 
through what methods and strategies and in what areas, the Iranian volleyball federation, as the main governing body of this discipline, can develop international sport diplomacy?

Ping pong diplomacy between the United States and the People's Republic of China in the early 1970s (Eckstein, 1993; Hong \& Sun, 2000; Kobierecki, 2016); Sport diplomacy in football and wrestling between the United States and Iran (Chehabi, 2001); Cricket diplomacy between India and Pakistan (Næss-Holm, 2007; Shahid, 2015); Sport diplomacy over the years between South Korea and North Korea (Merkel, 2008) are all examples of this, but the results were not the same in all cases.

\section{METHODS}

A qualitative study was designed to understand the practices and strategies of international sport diplomacy in the Iranian Volleyball Federation, a qualitative study is more appropriate when our information on the phenomenon under study is scarce. Semi structured interviews with knowledgeable subject matter experts were conducted systematically and continued using the snowball method. These experts included several groups, "These experts included several groups, officials $(\mathrm{O})$ from the Iranian Volleyball Federation $(\mathrm{N}=4)$, academic experts (AE) academic experts on sport diplomacy $(\mathrm{N}=4)$, and internationally experiences coaches and referees $(\mathrm{CR})$ internationally experienced coaches and referees $(\mathrm{N}=5)$. Interviews were completed at the theoretical saturation point and the data were analyzed using the thematic analysis technique. Of course, data collection and data analysis had a concurrent process, and research themes were developed in an inductive process. The interview protocol was sent to all the experts a few days before the interviews were conducted, though in each case it was possible to ask new questions and develop the discussion. The time and place of the interviews were coordinated with each expert, and each interview session lasted 30 to 45 minutes, and with the expert's consent and knowledge, the interviews were recorded and later transcribed. To perform the thematic analysis, the steps presented by Brown and Clark (2006) were used, which included six steps: Becoming familiar with the data, generating initial codes, searching for themes, reviewing themes, defining and naming themes, and Reporting is required (Braun \& Clarke, 2006). The Quality and Credibility of Qualitative Research Findings depend on distinct but interrelated factors including deep fieldwork and high-quality data collection; systematic data analysis; researcher's quality that depends on his background and experience and observing inductive analysis and purposeful sampling. Also, reflections of the 
participants in the study can enhance the quality and validity of the results (Patton, 2014). Therefore, the researchers took the following steps to ensure the quality and validity of the findings:

1- The reactions of the participants to the generated codes (reactions of responses) were obtained and the final results were confirmed by them.

2- Data were collected and analyzed simultaneously.

3- Appropriate samples were selected for interviews.

4- The process of building codes was reviewed and approved by a qualitative research expert.

\section{RESULTS}

To perform the thematic analysis, first by reading the text of the interviews several times, a general understanding of the terms and concepts in the text was obtained, and then an open coding was carried out. Each main theme included a number of sub-themes and basic codes, which are described below. The five main themes were challenges, the principles of effective international sport diplomacy, the success factors of international sport diplomacy, the development of international diplomacy in volleyball federation, and the implications of international sport diplomacy.

Officials (O)

Academic Experts (AE)

Coaches and Referees (CR)

\section{Theme \# 1: Challenges}

The first major theme appeared was named as Challenges. Challenges point to the many problems facing the Iranian Volleyball Federation in using international sport diplomacy. Of course, it can be acknowledged that other sports in Iran also face the same challenges in the field of international sport diplomacy. The main themes of the challenge consisted of three sub-themes including sovereignty challenges, challenges related to sanctions and sports structure challenges, some of the interviewee quotes are as follows:

"Some of the administrative processes in our country are really time-consuming and foreigners are unaware of the paperwork issues in our country which makes timely communication difficult (O1)". 
"When the Iranian referees, judge in international competitions, the World Federation does not pay the referee fees in cash, and given the difficulties we have in transferring money, there is a whole bunch of money in our account in Switzerland, but we cannot easily transfer it to the country (CR1)".

Table 1. The main themes of the challenges

\begin{tabular}{lll}
\hline $\begin{array}{l}\text { Main } \\
\text { theme }\end{array}$ & Sub-themes & Initial codes \\
\hline Challenges & Sovereignty & Bureaucracy \\
& & $\begin{array}{l}\text { The influence of the government on the Federation's International } \\
\text { Relations }\end{array}$ \\
\cline { 2 - 2 } & Sanctions & Shipping Transfer Problems \\
\cline { 2 - 2 } & Sport & Currency Problems \\
\cline { 2 - 2 } & Structure & Financial Problems \\
\end{tabular}

It can be said that overcoming challenges and tackling them may be the first step in the path of international sport diplomacy in the Iranian Volleyball Federation. Of course, some of these challenges (such as those posed by sanctions) are beyond the responsibility of the Federation and even the Iranian Ministry of Sport and are linked to the entire system of government in the country.

\section{Theme \# 2: Principles of Effective International Sport Diplomacy}

The second main theme that emerged was named the principles of effective international sport diplomacy. This main theme consists of three sub-themes: mutual respect, realism and the principle of sovereignty. In fact, these are the principles that must be followed in order to succeed in international sport diplomacy. The core of the rule referred to the more prominent presence of sport in the country's foreign policy, but two other sub-themes (mutual respect, realism) illustrate the general necessities that any organization (sport and non-sport) has to adhere to in international diplomacy.

Some quotes from the interviewees are as follows:

"International confidence is built in the long run, although I was Iranian myself, I was the supervisor of the various Iran-US, Iran-Japan, and other countries. This is because they knew me for a long time and I had shown my neutrality (CR2)". 
"I think whenever a political official such as our president goes to a foreign country, not only the Minister of Foreign Affairs but also the Minister of youth and sports should accompany him, as the sport is the simplest and most attractive way to resolve political disputes and problems with other countries (AE1)".

Table 2. The main theme of the principles and sub-themes and their related codes.

\begin{tabular}{|c|c|c|}
\hline Main Theme & Sub-themes & Initial codes \\
\hline \multirow[t]{6}{*}{$\begin{array}{l}\text { Principles of Effective International } \\
\text { Sport Diplomacy }\end{array}$} & $\begin{array}{l}\text { Mutual } \\
\text { Respect }\end{array}$ & $\begin{array}{l}\text { Understanding the legal differences } \\
\text { between countries }\end{array}$ \\
\hline & & Avoiding humiliating others \\
\hline & & Impartiality in international positions \\
\hline & & Having Cultural literacy \\
\hline & Realism & Realism in relationships \\
\hline & Sovereignty & $\begin{array}{l}\text { Stronger presence of sport in foreign } \\
\text { policy }\end{array}$ \\
\hline
\end{tabular}

\section{Theme \# 3: The Success Factors of International Sport Diplomacy}

The third main theme was named as the success factors of international sport diplomacy. This theme included sub-themes of stability, timing, mental, technical and manpower. The success factors are different from the principles (second theme), in fact, the principles stated in the second theme alone are not enough for international sport diplomacy. The principles are outlines and general guidelines but not applicable, but the factors contribute to the implementation of international sport diplomacy.

Some of the interviewee quotes are as follows:

"Timely international communication is very important, I remember when the President of the Japanese Federation came to Iran, and one of his grievances was that your correspondences were not done on time (CR3)".

"International relations officials in the country, including the Ministry of Foreign Affairs, diplomatic missions, the Ministry of Sport, the National Olympic Committee and even sports federations should document and share their valuable experiences in dealing with international issues and exchange with each other which enhances the capabilities of all these organizations (AE2)". 
Table 3. The main themes of success factors and the sub-themes and the related codes.

\begin{tabular}{|c|c|c|}
\hline Main Theme & Sub-themes & Initial codes \\
\hline \multirow{12}{*}{$\begin{array}{l}\text { The success factors } \\
\text { of the International } \\
\text { Relations of the } \\
\text { Federation }\end{array}$} & \multirow[t]{4}{*}{ Stability } & $\begin{array}{l}\text { Managerial Stability of International Relations } \\
\text { of the Federation }\end{array}$ \\
\hline & & $\begin{array}{l}\text { More interactions between the officials of } \\
\text { international relations in the country }\end{array}$ \\
\hline & & $\begin{array}{l}\text { Preservation of Iranian } \text { Members of } \\
\text { International Organizations }\end{array}$ \\
\hline & & The need for having a comprehensive plan \\
\hline & Timing & Timely international correspondence \\
\hline & Mental & $\begin{array}{l}\text { Disseminate an international approach } \\
\text { throughout the organization }\end{array}$ \\
\hline & \multirow[t]{2}{*}{ Technical } & Enjoying specialized information of the field \\
\hline & & $\begin{array}{l}\text { Knowledge Management of International } \\
\text { Relations }\end{array}$ \\
\hline & \multirow{4}{*}{$\begin{array}{l}\text { Empowering } \\
\text { staff }\end{array}$} & Investing in talented people \\
\hline & & $\begin{array}{l}\text { Training and development of international } \\
\text { relations skills }\end{array}$ \\
\hline & & $\begin{array}{l}\text { Developing international language skills, } \\
\text { especially English and French }\end{array}$ \\
\hline & & Powerful human resources \\
\hline
\end{tabular}

\section{Theme 4: International Diplomacy Development Strategies in Volleyball Federation}

The fourth major theme emerged was the development of international diplomacy strategies in the volleyball federation. If the challenges mentioned in the first theme are resolved, by observing the principles (the second theme) and the availability of success factors (the third theme) the strategies of international diplomacy in the volleyball federation can be performed. In other words, the strategies are referred to as the operational areas of international diplomacy in the volleyball federation. The main themes of the strategies included the sub-themes of acquiring hosting, acquiring seats, enhancing internal interactions, becoming a regional hub, and sending out manpower. Some of these strategies are directly related to international sport diplomacy operations, but others have a supportive role; enhancing internal interactions is a supportive strategy for implementing other strategies. Some of the interviewee quotes are as follows:

"Our volleyball situation is now so that we can serve as an intermediary link between fully developed and underdeveloped countries. Look, there are a number of countries that are well advanced in various fields, including volleyball. But on the other side, we have countries that are lower in terms of development indicators. The second group of countries is keen to advance in volleyball. When we 
are part of the first group of countries in volleyball, we can use this capacity in various volleyball development issues of the second group. This action could also be welcomed by relevant international organizations, including the IOC and the World Federation (AE3)".

"We have to start communicating with successful and orderly federations around the world such as Italy. This will help different sectors, especially international relations (O4)”.

Table 4. The main theme of the strategies and the sub-themes and the related codes.

\begin{tabular}{|c|c|c|}
\hline Main Theme & Sub-themes & Initial codes \\
\hline \multirow{14}{*}{$\begin{array}{l}\text { International } \\
\text { Diplomacy } \\
\text { Development } \\
\text { Strategies in } \\
\text { Volleyball } \\
\text { Federation }\end{array}$} & acquiring & Hosting international refereeing and coaching courses \\
\hline & hosting & \\
\hline & \multirow{3}{*}{$\begin{array}{l}\text { acquiring } \\
\text { seats }\end{array}$} & Gaining international seats \\
\hline & & Lobbying with other countries \\
\hline & & Use the valuable experiences of leading countries \\
\hline & \multirow{2}{*}{$\begin{array}{l}\text { enhancing } \\
\text { internal } \\
\text { interactions }\end{array}$} & Finding strong national sponsors \\
\hline & & Using the academic ability of Iranian universities \\
\hline & \multirow[t]{4}{*}{$\begin{array}{l}\text { becoming a } \\
\text { regional hub }\end{array}$} & $\begin{array}{l}\text { Becoming the intermediary between developed and } \\
\text { underdeveloped countries }\end{array}$ \\
\hline & & $\begin{array}{l}\text { Establishing the International Academy of Volleyball } \\
\text { Development in the country }\end{array}$ \\
\hline & & Teaching Related sciences \\
\hline & & Teaching supporting sciences \\
\hline & \multirow{3}{*}{$\begin{array}{l}\text { export of } \\
\text { manpower }\end{array}$} & Sending out coaches \\
\hline & & Sending out referees \\
\hline & & Sending out players \\
\hline
\end{tabular}

\section{Theme \# 5: Implications for International Sport Diplomacy}

The last (fifth) main theme was named implications. Implications imply that if the Iranian Volleyball Federation successfully implements international sport diplomacy strategies, there will be positive implications. Implications had two sub-themes: general and sports implications and point to the positive results of these two areas. In fact, the general implications are the ability of sport as a tool of public diplomacy to improve the country's image in the world, to recognize the country's tourist attractions to the world, the means of international interactions, and to overcome negative publicity. This area has been heavily emphasized in research and refers to the high capacity of sport. 
But the success in the development of desirable international sport diplomacy also opens up unique opportunities for the development of volleyball. Some of the interviewee quotes are as follows:

"Despite all the different problems that we faced internationally, the different sanctions, the negative publicity, and a lot of other ones, we have been able to bring in different teams, even the US and other teams, and this is a testament to the power of sports in international diplomacy (O4)".

"When we hosted the Nations' League in different provinces, the best hosting took place, and media coverage around the world from different provinces and cities was the best way to identify the country's attractions to foreigners (CR4)".

Table 5. The main themes of the implications and the sub-themes and the related codes.

\begin{tabular}{|c|c|c|}
\hline Main Theme & Sub-themes & Initial codes \\
\hline \multirow{6}{*}{$\begin{array}{l}\text { Implications of } \\
\text { International Sport } \\
\text { Diplomacy }\end{array}$} & \multirow[t]{5}{*}{ General } & To improve the country's \\
\hline & & image in the world \\
\hline & & $\begin{array}{l}\text { To recognize the country's } \\
\text { tourist attractions to the world }\end{array}$ \\
\hline & & $\begin{array}{l}\text { The means of international } \\
\text { interactions }\end{array}$ \\
\hline & & $\begin{array}{l}\text { To overcome negative } \\
\text { publicity }\end{array}$ \\
\hline & Sport opportunities & $\begin{array}{l}\text { Attracting international } \\
\text { opportunities for the } \\
\text { development of volleyball }\end{array}$ \\
\hline
\end{tabular}

After finalizing the themes and defining and naming themes, by drawing the thematic map, we can better understand how the themes interact and relate. Figure 1 shows the final thematic map. 


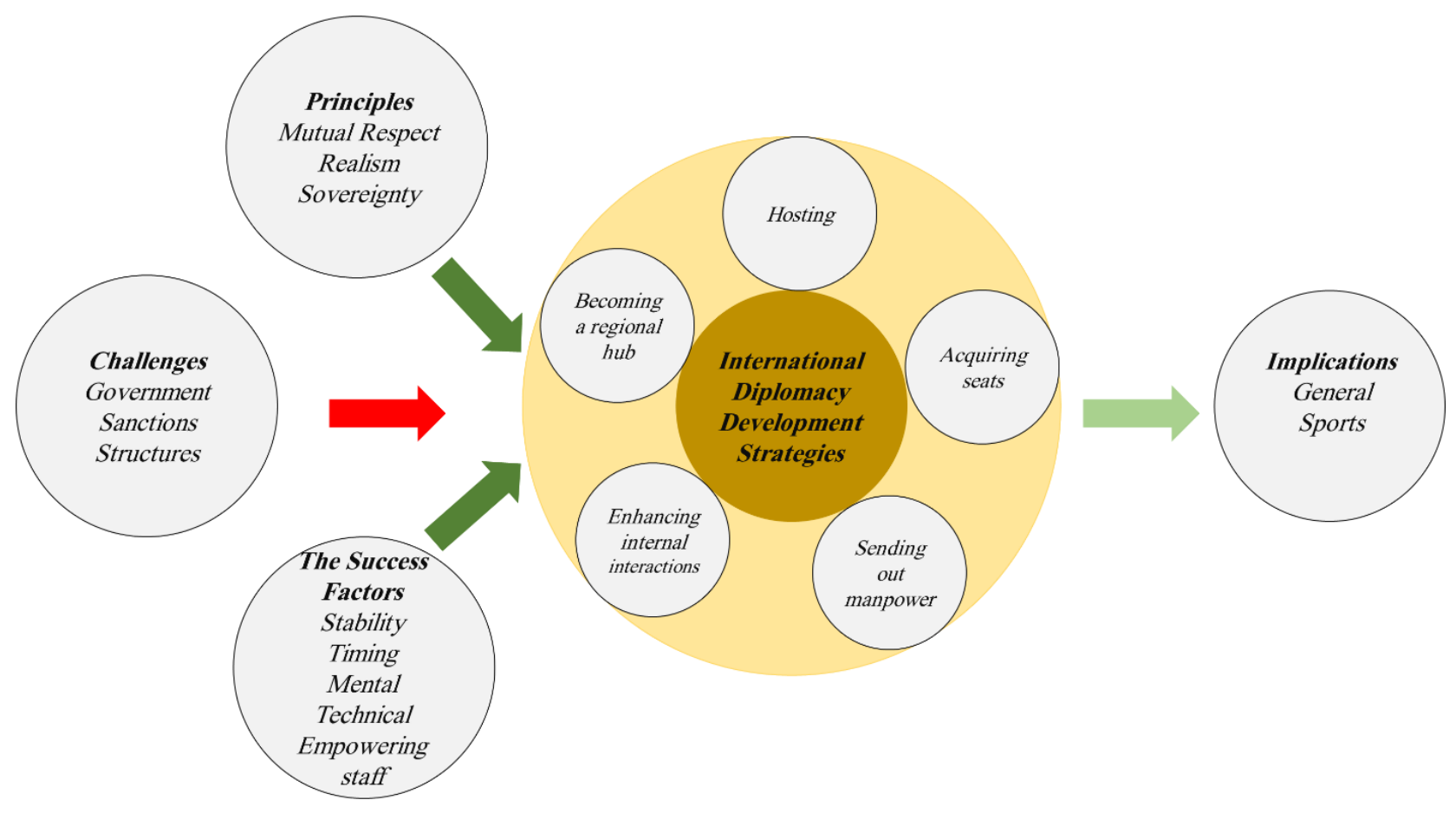

Figure 1. Thematic map

\section{DISCUSSION AND CONCLUSIONS}

In the last century, international sport has more than ever been the site of political games in different countries. Political upheavals have sometimes gone so far as to prevent contests and sporting events. This aspect refers to the pervasiveness of sport to politics, that is, deep political divisions can overshadow sporting events and impede the normal flow of sport worldwide. Sport diplomacy is also a concept with a long history of intergovernmental relations and has repeatedly served as an effective and efficient tool for improving the relations and atmosphere of interactions between nations and countries, but the reality is that different mechanisms and operational aspects of it are unknown. This may be due to the complex nature of international relations and the specificity of each interactive situation relative to other situations. For example, the Function and Processes taken place in the cases of Ping Pong Diplomacy between the United States and the People's Republic of China in the Early 1970s (Eckstein, 1993; Hong \& Sun, 2000; Kobierecki, 2016); Sport Diplomacy in Football and Wrestling Between the United States and Iran (Chehabi, 2001); cricket diplomacy between India and Pakistan (Næss-Holm, 2007; Shahid, 2015) and sport diplomacy between South and North Korea (Merkel, 2008) have definitely been different from each other because the context of the event and many of its causes were different. 
The use of international sport as a diplomatic tool has been accepted by almost all governments and even many people around the world are aware of it, but the processes of international-sport-asdiplomacy are largely unknown because Basically, the actors of this type of diplomacy while being important and in front of the eyes, are neglected. Today, in addition to national governments, which are primarily responsible for supporting and sponsoring international sporting events, many non-state actors play an international role in the area of international sports the most important of which are IOC, FIFA, FIVB, etc., local governments, municipalities, sponsors, and so on should also be add to these organizations. The quality and relationships between these actors have been of less interest to researchers internationally, and public opinion is less aware of them, and only the results of these communications in the form of exciting competitions of sporting events are watched.

The Iranian Volleyball Federation, as one of the subsidiaries of the national federations of the FIVB and AVC, is responsible for developing volleyball in Iran and represents the FIVB and AVC. The sport of volleyball has made significant progress in recent years in Iran, and this development has provided Iran with good opportunities for international interactions. Using qualitative methods, this study studied strategies and fields of development of international-sport-as-diplomacy in the Iranian Volleyball Federation because of the importance of a desired and successful international diplomacy for the Iranian Volleyball Federation. According to the results, five main themes emerged in the research: Challenges, Principles of Effective International Sport Diplomacy, Success Factors of International Sport Diplomacy, International Diplomacy Development Strategies in Volleyball Federation, and Implications of International Sport Diplomacy. Each of these themes pointed to a specific conceptual area.

However, despite the separation of the above five concepts, the total findings of this study should be understood and analyzed as a whole, because the success of the implementation of international sport diplomacy also depends on taking into account all of the above factors. According to the final thematic map presented for the implementation of international sport diplomacy development strategies, the Volleyball Federation of Iran must address the three governance challenges arising from sanctions and structure. To implement the five strategies by observing the principles of diplomacy and considering the success factors of international sport diplomacy, and if this path is followed correctly, the consequences of implications (public and sports) will not be far from expectation.

The challenges highlighting the current problems of the volleyball federation in using international-sport-as-diplomacy must be resolved. These challenges are due to the state structure and sports system of the country, which are internal factors. Part of it is due to international sanctions 
against Iran. However, the Iranian Volleyball Federation may not be able to resolve all of its challenges, but it must adjust as far as possible. Of course, the challenges facing the Volleyball Federation of the Islamic Republic of Iran are only part of the overall state of sports diplomacy in Iran. In general, the sport of the Islamic Republic of Iran has gone through ups and downs after the 1979 revolution, and although it has experienced a growing trend in the international arena, but from the perspective of sports diplomacy, it has not yet found a suitable model for Iran. Politicians in the field of diplomatic relations of Iran, unlike many countries in the world, also do not have a proper understanding of the diplomatic power of athletes, referees, coaches and the sporting position of Iran in general, in other words, consider the phenomenon of sport and diplomatic power insignificant. Therefore, despite the instrumental and indirect use of sports by other countries to convey their message to the international community, this issue has not been considered in the diplomatic apparatus of Iran.

The Principles of Effective International Sport Diplomacy were the second theme that the Federation must consider. These principles are the principles that were essential to the success of international relations everywhere; mutual respect, realism and the principle of sovereignty, three principles that were identified. These principles appear to be emphasized in most international treaties, for example in Wilson's Fourteen Principles emphasizing the openness and integrity of international relations and diplomacy and their impartiality (Throntveit, 2011) or in the Treaty of Versailles, Reciprocity has been mentioned (Lu, 2002). The issue of mutual respect with international relations cooperation theories can also be debated, one of which is the theory of interdependence (Pevehouse, 2004) It must be admitted that although the above principles are obvious and necessary for the success of diplomatic relations (even in general), unfortunately the historical mentality of Iranians has made it difficult to accept and observe the above principles. The historical background of Iran and the ownership of one of the largest historical empires in the world, although it is a source of pride for Iranians, has made Iranians unrealistic in their interaction with other nations of the world and are somewhat arrogant, while in the present era world equations have changed. To succeed in diplomatic relations, accepted principles must be at the forefront. In other words, if in the field of sport diplomacy in Iran and Iranian sports organizations want success, while accepting the principles of diplomatic relations, they should make appropriate efforts to achieve the desired situation.

The other theme was the success factors of International Sport Diplomacy in the Iranian Volleyball Federation, which highlighted the technical and human needs and requirements for the successful implementation of International Sport Diplomacy Strategies. Stability, timing, subjective and technical factors, and human resource empowerment were all mentioned. The next major theme 
was the development of international diplomacy strategies in the Iranian Volleyball Federation, which was a core of the research findings and referred to the Iranian Federation's practical actions. Strategies can be implemented by resolving challenges and adhering to the principles and by the availability of factors; these include acquiring hosting, acquiring international seats, enhancing interactions, becoming a regional hub and transferring specialist human resources that can serve as international diplomacy that can promote the international diplomacy of the Iranian Federation to a higher level. As mentioned in the previous theme, it must be borne in mind that the acceptance of the Principles of Effective International Sport Diplomacy alone will not provide the grounds for success in this field, and in order to reach the desired point, operational tools must be provided. This theme was mentioned.

The last theme identified was also the implications of international sport diplomacy, which was related to the outcomes of international sport diplomacy. These results are of two categories: public and sport outcomes, public outcomes are in fact the first type of international sport relations and diplomacy in Murray and Pigman's (2014) research, which has also been emphasized in various studies; Cha (2013); Grieks and Holliday (2014); Stolajter and Stolajter (2016) and Cha (2016) are studies that have all emphasized the ability of sport to enhance international interactions between countries and the effectiveness of sport communication as a tool of diplomacy (Cha, 2013, 2016; Grix \& Houlihan, 2014; ultulajer \& Štulajter, 2016, Fullerton et al (2018) and Min and Choi (2019).

In fact, the present study sought to fill the gap posed by Mary and Pigman (2014), who described the lesser-known and studied type of international sport diplomacy, international-sport-asdiplomacy. This type of diplomacy refers to the totality of diplomatic relations and actions during international sport competitions, which was also referred to by Dennis and Greeks (2012) as the internal dimension of the political use of sport, which was opposite to the external dimension. Accordingly, in this study, the findings related to the theme of strategies were related to the development of international-sport-as-diplomacy or the internal dimension of the political use of sport, which was specifically related to the Volleyball Federation of Iran. Implementing these strategies can use international sport to develop its international relations.

But the implications of sport, although less emphasized in other researches, appear to be the obvious results of the establishment of international sport diplomacy by the Iranian Federation, pointing to the volleyball, benefiting from the provided opportunities. Overall, this study, consistent with theoretical foundations and other researches, pointed to the usefulness and effectiveness of international diplomacy through sport. But in particular, it identified under which factors and areas, international-sport-as-diplomacy development strategies within the Iranian Volleyball Federation are 
applicable. Therefore, the findings of this study can be applied to the development of internationalsport-as-diplomacy in the Iranian Volleyball Federation.

Of course, in the end, it is necessary to point out some limitations facing the researcher; one of the limitations was the small number of capable specialists in the field of sport diplomacy in Iran. Sport diplomacy is an interdisciplinary field that is even less known in the world and does not have its own academic specialists because it is less known as an independent field. Therefore, there are few people who can comment in the field of sport diplomacy, and their information is based solely on practical experience or study interests. The second limitation is the scarcity of study resources in the field of international-sport-as-diplomacy, as noted, and according to Murray and Pigman (2014) the first type of sport diplomacy, the conscious use of international sport by governments as a diplomatic tool, is common. And most studies have focused on this dimension, but the second type (international-sport-as-diplomacy) has received less attention, so the researcher took steps to develop the second type and hopes that the findings of this study can be considered further by other researchers to develop international-sport-as-diplomacy.

\section{REFERENCES}

1. Bazić, J. (2018). The Social Aspects of Sport. Physical Education and Sport Through the Centuries, 5(1), 49-66. https://doi.org/10.2478/spes-2018-0005

2. Braun, V., \& Clarke, V. (2006). Using thematic analysis in psychology. Qualitative research in psychology, 3(2), 77-101.

3. Cha, V. (2013). The Asian Games and Diplomacy in Asia: Korea-China-Russia. The International Journal of the History of Sport, 30(10), 1176-1187.

4. Cha, V. (2016). Role of sport in international relations: National rebirth and renewal .Asian Economic Policy Review, 11(1), 139-155.

5. Chehabi, H. E. (2001). Sport diplomacy between the United States and Iran. Diplomacy and Statecraft, 12(1), 89-106.

6. Dennis, M., \& Grix, J. (2012). Sport Under Communism: Behind the East German 'Miracle': Palgrave Macmillan.

7. Eckstein, R. (1993). Ping pong diplomacy: A view from behind the scenes. Journal of American-East Asian Relations, 2(3), 327-342.

8. Essays, U. (2018). Role of Sport In Modern Society Cultural Studies Essay. Retrieved from https://www.ukessays.com/essays/cultural-studies/role-of-sport-in-modern-society-culturalstudies-essay.php?vref=1 
9. FIVB. (2019). FIVB SENIOR WORLD RANKING - MEN. Retrieved from https://www.fivb.com/en/volleyball/rankings/rankingseniormen

10. FIVB. (2020). $\quad$ VOLLEYBALL HISTORY $\quad$.Retrieved from http://www.fivb.org/en/volleyball/History.asp

11. Fullerton, J., Abdi, K., Talebpour, M., Ranjhesh, M., \& Nooghabi, H. (2018). Converting sports diplomacy to diplomatic outcomes: introducing a sport diplomacy model Article resue guideline. International area studies review, 4(11), 1-17.

12. Grix, J., \& Houlihan, B. (2014). Sports Mega-Events as Part of a Nation's Soft Power Strategy: The Cases of Germany (2006) and the UK (2012). The British Journal of Politics and International Relations, 16(4), 572-596. https://doi.org/10.1111/1467-856X.12017

13. Hong, Z., \& Sun, Y. (2000). The Butterfly Effect and the Making of'Ping-Pong Diplomacy'. Journal of Contemporary China, 9(25), 429-448.

14. International Olympic Committee. (2019). Olympic charter: In force as from 26 June 2019. Switzerland: International Olympic Committee.

15. Kobierecki, M. M. (2016). Ping-Pong Diplomacy and its Legacy in the American Foreign Policy. Polish Political Science Yearbook, 45(1), 304-316.

16. Lu, C. (2002). Justice and moral regeneration: lessons from the Treaty of Versailles. International Studies Review, 4(3), 3-25.

17. Merkel, U. (2008). The politics of sport diplomacy and reunification in divided Korea: One nation, two countries and three flags. International Review for the Sociology of Sport, 43(3), 289-311.

18. Min, D., \& Choi, Y. (2019). Sport cooperation in divided Korea: an overstated role of sport diplomacy in South Korea. Sport in Society, 22(8), 1382-1395.

19. Murray, S. (2012). The two halves of sports-diplomacy. Diplomacy \& statecraft, 23(3), 576592 .

20. Murray, S., \& Pigman, G. A. (2014). Mapping the relationship between international sport and diplomacy. Sport in Society, 17(9), 1098-1118.

21. Næss-Holm, A. (2007). Batting for peace: A study of cricket diplomacy between India and Pakistan. (Master's Thesis in Peace and Conflict Studies), UNIVERSITETET I OSLO.

22. Patton, M. Q. (2014). Qualitative Research \& Evaluation Methods: Integrating Theory and Practice: SAGE Publications.

23. Pevehouse, J. C. (2004). Interdependence theory and the measurement of international conflict. The Journal of Politics, 66(1), 247-266. 
24. Shahid, S. A. (2015). INDIA: PAKISTAN Sports as a Tool for Peace (Cricket Diplomacy). International Journal of Coaching Science, 9(1), 51-63.

25. Štulajer, I., \& Štulajter, M. (2016). Significance of Sport in International Relations. Journal of Modern Science, 2(29), 381-388.

26. Throntveit, T. (2011). The fable of the Fourteen Points: Woodrow Wilson and national selfdetermination. Diplomatic History, 35(3), 445-481.

27. United Nations. (2020a). International Day of Sport for Development and Peace 6 April. Retrieved from https://www.un.org/en/events/sportday/

28. United Nations. (2020b). The United Nations and the Olympic Truce. Retrieved from https://www.un.org/en/events/olympictruce/

\section{APPENDIX}

\section{Interview Questions}

-Briefly describe your background in international relations.

- What do you think are the components of a successful international relationship for an NGO? Which of these components can be used in sports such as the Volleyball Federation of the Islamic Republic of Iran?

- How do you see the current state of international relations of the Volleyball Federation of the Islamic Republic of Iran? (If you do not know the exact status of this federation, consider the status of international relations of other sports organizations).

- What are the challenges facing the establishment of favorable international relations by Iranian sports organizations such as the Volleyball Federation of the Islamic Republic of Iran?

- Do you think that the establishment of favorable international relations by Iranian sports organizations such as the Volleyball Federation of the Islamic Republic of Iran can help the country's public diplomacy?

- If you have any other opinion on the subject of research, please. 
Fallah Nassiri et al.

\section{AUTHOR CONTRIBUTIONS}

All authors listed have made a substantial, direct and intellectual contribution to the work, and approved it for publication.

\section{CONFLICTS OF INTEREST}

The authors declare no conflict of interest.

FUNDING

This research received no external funding.

\section{COPYRIGHT}

(C) Copyright 2022: Publication Service of the University of Murcia, Murcia, Spain. 